\title{
Does ICT Penetration Enhance Tax Revenue?: Panel Evidence
}

\author{
BiT Kullanımının Yaygınlaşması Vergi Gelirini Arttırır mı?: Panel Kanıt
}

\section{Prof. Dr. Cüneyt Koyuncu - Prof. Dr. Rasim Yılmaz - Asst. Prof. Dr. Mustafa Ünver}

\begin{abstract}
In this study, we explore the impact of ICT penetration on tax revenue. We test the hypothesis that ICT penetration contributes to increase in tax revenue by examining an unbalanced panel data set including the period 1990 to 2013 and using four ICT penetration indicators and three tax revenue indicators. Our largest sample includes 157 countries. We identified highly statistically significant positive correlation between ICT penetration and tax revenue by using univariate and multivariate time effect models. This finding is statistically significant and valid for four ICT penetration indicators and three tax revenue indicators. Our results suggest that ICT penetration increases tax revenue across countries between 1990 and 2013, controlling for other factors that may contribute to increase in tax revenue.
\end{abstract}

Keywords: ICT Penetration, Revenue Performance, Taxes, Panel Study

\section{Öz}

Bu çalı̧şmada, Bilgi İşlem Teknolojileri (BİT) kullanıminın yaygınlaşmasının vergi geliri üzerindeki etkisi araştırılmıştır. Bilgi İşlem Teknolojileri (BİT) kullanımının yaygınlaşmasının ülke vergi gelirinin artmasına katkı sağlayacağı hipotezi 1990-2013 dönemini kapsayan dengesiz panel veri, dört BİT penetrasyon göstergesi ve üç ülke vergi geliri göstergesi kullamilarak test edilmiştir. Çalışmanın en büyük örnekleminde 157 ülke vardır. Tek ve çok değgişkenli zaman etkisi modelleri kullanilarak BİT penetrasyonu ve ülke vergi geliri arasinda istatistiksel olarak anlaml pozitif korelasyon tespit edilmiştir. Bu bulgu, dört BİT penetrasyon göstergesi ve üç vergi geliri göstergesi için de istatistiksel olarak anlaml ve geçerli bulunmuştur. Ülkeler arası araştırma sonuçlarımız, ülke vergi gelirlerinin artışına etki eden diğer faktörlerin kontrol altında tutulması koşulları altında, BİT kullanımının yaygınlaşmasının ülke vergi gelirlerinin artmasına katkı sağlayacağını göstermektedir.

Anahtar Kelimeler: BİT Kullanımının Yaygınlaşması, Gelir Performansı, Vergiler, Panel Veri Çalışması

\section{Introduction}

Determinants of tax revenue have been the subject of widespread debate in the relevant literature. Country level and cross country empirical studies on the determinants of tax revenue reveal the following factors as main determinants of tax revenue: GDP per capita, the sectoral composition of the GDP, the level of foreign direct investment (FDI), trade openness and the level of public debt. Macroeconomic variables such as exchange rate, inflation rate; institutional factors like corruption, law and order, voice and accountability, civil and political rights, the level of democracy, government stability, political stability and economic stability; social variables such as the educational level,

Prof. Dr. Cüneyt Koyuncu, Bilecik Seyh Edebali University The Faculty of Economics and Administrative Sciences, cuneyt.koyuncu@bilecik.edu.tr Prof. Dr. Rasim Yilmaz, Namik Kemal University The Faculty of Economics and Administrative Sciences, rasimyilmaz@nku.edu.tr Asst. Prof. Dr. Mustafa Ünver, Gümüşhane University The Faculty of Economics and Administrative Sciences, mustafaunver@gumushane.edu.tr 
population growth are also considered determinants of tax revenue in the relevant literature (Chelliah, Baas and Kelly, 1975; Tait, Gratz and Eichengreern, 1979; Leuthold, 1991; Tanzi 1992; Cassou, 1997; Tanzi 1998; Stotky and Wolde-Mariam, 1997; Ghura, 1998; Piancastelli, 2001; Bird, Martinez-Vasquez and Torgler, 2004; Teera and Hudson, 2004; Bahl and Wallace, 2005; Gugler and Brunner, 2007; Bird, Martinez-Vasquez and Torgler, 2008; Gupta, 2007; Pessino and Fenochietto, 2010; Castro and Camarillo, 2014).

Besides other factors mentioned in the literature, ICT penetration may contribute to increase in tax revenue. Penetration of internet, fixed broadband, personal computers, and mobile phones across nations have significantly accelerated in the world since the beginning of 1990s. The penetration of internet, on average, increased from 0.55 (percentage of individual using the internet) in the period of 1990-1994 to 39.02 in the period of 2010-2013. On the other hand the penetration of personal computers reached 19.16 (per 100 people) in the period of 2005-2009 from 4.64 in the period of 1990-1994.

Intuitively, ICT penetration affects tax revenue through affecting the factors which lead to raise the level of output and economic growth. ICT penetration reduces production costs, promote demand and investment, improve efficiency of resource allocation whereby raise the level of output and economic growth which may lead to increase in tax revenue (Vu, 2011; Pradhan et al. 2014). Moreover, tax collection, administration, and monitoring become easier with ICT penetration which may eventually cause to increase in tax revenue. For example, the government in England have recently started using digital tax accounts as a part of modernize the tax system. Under this system, tax payers can check their tax information online, know how much they owe, and have the option to pay as they go. This system ensures tax payers to manage their cash flow better since they have more certainty regarding what they need to pay and when (HM Revenue and Customs, 2015).

Therefore, in this study, we examine the impact of ICT penetration on tax revenue in a particular country. For this purpose, we test the hypothesis that ICT penetration contributes to increase in tax revenue by utilizing an unbalanced panel data set inclu- ding the period 1990 to 2013 and four ICT penetration indicators and three tax revenue indicators. To our best knowledge, this is the first empirical study in the literature addressing to aforementioned issue for 157 countries by using four ICT penetration proxies and three tax revenue indicators. Our findings indicate highly statistically significant positive correlation between ICT penetration and tax revenue for four ICT penetration indicators and three tax revenue indicators. According to results, ICT penetration enhances tax revenue across countries between 1990 and 2013, controlling for other factors that may contribute to tax revenue.

This article proceeds as follows. In the following section we introduce our data, model, and our empirical strategy. Estimation results are given in section 3 . We offer concluding thoughts in the final section.

\section{Empirical Framework}

We investigated the impact of ICT penetration on tax revenue by using 4 ICT indicators and 3 tax revenue indicators. The period under study is between 1990 and 2013. Our largest sample includes 157 countries. $^{1}$

1 The sample includes the following countries: Afghanistan, Albania, Algeria, Angola, Antigua and Barbuda Argentina, Armenia, Australia, Austria, Azerbaijan, Bahamas, Bahrain, Bangladesh, Barbados, Belarus, Belgium, Belize, Benin, Bhutan, Bolivia, Bosnia and Herzegovina, Botswana, Bulgaria, Burkina Faso, Burundi, Cambodia, Cameroon, Canada, Cape Verde, Central African Rep., Chad, China, Colombia, Congo, Costa Rica, Cote d'Ivoire, Croatia, Cyprus, Czech Republic, Denmark, Dominica, Dominican Republic, Egypt, El Salvador, Equatorial Guinea, Estonia, Ethiopia, Fiji, Finland, France, Gambia, Georgia, Germany, Ghana, Greece, Grenada, Guatemala, Guinea, Honduras, Hong Kong, Hungary, Iceland, India, Indonesia, Iran, Ireland, Israel, Italy, Jamaica, Japan, Jordan, Kazakhstan, Kenya, Kiribati, Korea Republic, Kuwait, Kyrgyzstan, Lao P.D.R., Latvia, Lebanon, Lesotho, Liberia, Lithuania, Luxembourg, Macao, Macedonia, Madagascar, Maldives, Malaysia, Mali, Malta, Mauritius, Mexico, Moldova, Mongolia, Morocco, Mozambique, Myanmar, Namibia, Nepal, Netherlands, New Zealand, Nicaragua, Niger, Nigeria, Norway, Oman, Pakistan, Panama, Papua New Guinea, Paraguay, Peru, Philippines, Poland, Portugal, Qatar, Romania, Russian Federation, Rwanda, Saint Lucia, Samoa, Serbia, Seychelles, Sierra Leone, Singapore, Slovakia, Slovenia, South Africa, Spain, Sri Lanka, Sudan Republic, Suriname, Sweden, Switzerland, Syrian Arab Republic, Tajikistan, Thailand, Tanzania, Tonga, Trinidad and Tobago, Tunisia, Turkey, Uganda, Ukraine, United Arab Emirates, United Kingdom, United States, Uruguay Vanuatu, Venezuela, Yemen, Zambia, Zimbabwe. 
By using unbalanced panel data and a sample including developed and developing countries, we estima- te the following bivariate and multivariate fixed time effect models $(\mathrm{FEM})^{2}$;

$$
\begin{aligned}
& \text { TAXREV }_{i t}=\left(\alpha+\tau_{t}\right)+\beta_{1} I C T_{i t}+u_{i t} \\
& \text { TAXREV }_{i t}=\left(\alpha+\tau_{t}\right)+\beta_{1} I C T_{i t}+\beta_{2} \text { GDPPCGRO }_{i t}+\beta_{3} \text { FDI }_{i t}+\beta_{4} \text { OPENNESS }_{i t}+u_{i t}
\end{aligned}
$$

and the following bivariate and multivariate random time effect models (REM);

$$
\begin{aligned}
& \text { TAXREV }_{i t}=\alpha+\beta_{1} I_{C T}+\left(\tau_{t}+u_{i t}\right) \\
& \text { TAXREV }_{i t}=\alpha+\beta_{1} \text { ICT }_{i t}+\beta_{2} \text { GDPPCGRO }_{i t}+\beta_{3} F I_{i t}+\beta_{4} \text { OPENNESS }_{i t}+\left(\tau_{t}+u_{i t}\right)
\end{aligned}
$$

where it subscript stands for the $i$-th country's observation value at time $t$ for the particular variable. $\alpha$ is the intercept term and $\tau_{\mathrm{t}}$ represents time-specific effects which affect all countries in the same way. $u_{i t}$ is idiosyncratic error term of the regression model.

Our dependent variable is tax revenue. Three different tax revenue indicators are used in order to evaluate the sensitivity of our empirical results. Results may vary depending on which tax revenue indicator is used. If the results hold across different tax revenue indicators, it will be an indication of their robustness.
The list of dependent variables, their definitions, and the data sources are given in Table 1 below.

TAXREV is tax revenue as a percentage of GDP. GOODTAX is taxes on goods and services as a percentage of value added of industry and services. VAT is a value added tax as a percentage of GDP. Data on tax revenue as a percentage of GDP, taxes on goods and services as a percentage of value added of industry and services, and GDP (current LCU) are taken from WDI while revenue value-added taxes (central government budget) data are taken from Government Finance Statistics of IMF.

Table 1. List of Dependent Variables

\begin{tabular}{|l|l|l|}
\hline Variables & Definition & Source \\
\hline TAXREV & Tax revenue (\% of GDP) & WDI \\
\hline GOODTAX & $\begin{array}{l}\text { Taxes on goods and services (\% value added of industry } \\
\text { and services) }\end{array}$ & WDI \\
\hline VAT & $\begin{array}{l}\text { Revenue Value-added Taxes, Cash (Budg. Cen. Govt.) } \\
\text { (current LCU) / GDP (current LCU) }]^{* 100}\end{array}$ & $\begin{array}{l}\text { IMF, Government Finance } \\
\text { Statistics (GFS) } \\
\text { WDI }\end{array}$ \\
\hline
\end{tabular}

Our explanatory variables were chosen in the light of previous studies found in the literature and our main hypothesis. ICT penetration in above models is represented by four variables. Definition and data source of ICT penetration variables are given in Table 2 below.

We also introduced three more determinants of tax revenue variable into our analysis based on evidence
2 We used time effect model for two reasons. Firstly, as the period of estimation (1990-2013) is one in which interest in ICT products has been rising quite rapidly all over the world, we used period effect model instead of country-specific effect model in order to capture the impact of this particular fact on tax revenues. Secondly, since country-specific effect model requires estimation of more coefficients (i.e. country-specific coefficients) than period effect model, thus reducing degrees of freedom and potentially draining statistical power of estimators, the period-effect model is chosen. 
Table 2. List of ICT Variables

\begin{tabular}{|c|c|c|}
\hline Variables & Definition & Source \\
\hline INTERNET & $\begin{array}{l}\text { Percentage } \\
\text { of } \\
\text { individuals } \\
\text { using the } \\
\text { Internet }\end{array}$ & $\begin{array}{l}\text { World Telecommunication/ICT Indicators Database of UN } \\
\text { Database } \\
\text { http://data.un.org/Data.aspx?d=ITU\&f=ind1Code } \% 3 \text { aI } 99 \mathrm{H \# ITU}\end{array}$ \\
\hline CELLPHONE & $\begin{array}{l}\text { Mobile- } \\
\text { cellular } \\
\text { telephone } \\
\text { subscriptions } \\
\text { per } 100 \\
\text { inhabitants. }\end{array}$ & http://www.itu.int/en/ITU-D/Statistics/Pages/stat/default.aspx \\
\hline COMPUTER & $\begin{array}{l}\text { Personal } \\
\text { Computers } \\
\text { per } 100 \\
\text { people. }\end{array}$ & International Telecommunication Union \\
\hline FXBROADBAND & $\begin{array}{l}\text { Fixed } \\
\text { broadband } \\
\text { subscriptions } \\
\text { (per } 100 \\
\text { people) }\end{array}$ & $\begin{array}{l}\text { International Telecommunication Union, World } \\
\text { Telecommunication/ICT Development Report and database. }\end{array}$ \\
\hline
\end{tabular}

Table 3. List of Independent Variables

\begin{tabular}{|l|l|l|}
\hline Variables & Definition & Source \\
\hline GDPPCGRO & GDP per capita growth (annual \%) & WDI \\
\hline FDI & Foreign Direct Investment, Percentage of Gross Fixed Capital Formation & UNCTAD \\
\hline OPENNESS & $\begin{array}{l}{[\text { [Exports of goods and services (current US\$)+ Imports of goods and }} \\
\text { services (current US\$)]/ GDP (current US\$) }]^{*} 100\end{array}$ & WDI \\
\hline
\end{tabular}

from existing literature to see how robust our finding is. Definition and data source of other independent variables besides ICT variables are given in Table 3 below.

The following further describes the independent variables and discusses their expected signs.

GDPPCGRO is the annual GDP per capita growth. The coefficient on the GDP per capita variable is expected to have positive sign in our model since tax revenue of a country will increase as the level of economic development of a country increases (Gupta, 2007). The data on annual GDP per capita growth come from WDI.

FDI is the foreign direct investment as a percentage of Gross Fixed Capital Formation. The expected sign of FDI variable is ambiguous. On the one hand, flows of foreign direct investment may lead to decrease in tax revenue due to fiscal incentives and subsidies provided to foreign investors. On the other hand, flows of foreign direct investment may lead to increase in tax revenue due to increase in competitiveness and the formalization of the economy as a result of FDI flows (Cassou, 1997; Gugler and Brunner, 2007; Castro and Camarillo, 2014). The data is taken from UNCTAD.

Openness is computed by the ratio of imports of goods and services (current USD) plus exports of goods and services (current USD) to GDP (current USD) of the relevant country. The expected sign of OPENNESS variable is also ambiguous. On the one hand, an open economy may diminish tax revenue due to reductions in tariffs as a result of trade liberalization. On the other hand, an open economy may lead to increase in tax revenue due to increase in the size, formalization and the competitiveness of the economy 
as trade expands (Gupta, 2007; Castro and Camarillo, 2014). Exports of goods and services, imports of goods and services data, and GDP data used in creation of openness variable are from World Development Indicators of the World Bank.

\section{Estimation Results}

The results of bivariate and multivariate estimations are reported in Table 4-7 and Table 8-11 respectively below for four different ICT indicators. Each Table has 3 models for 3 different tax revenue indicators.
Hausman test is used for the selection between fixed time effect model and random time effect model and decision is made at $5 \%$ significance level.

The results of bivariate models show that all coefficients of INTERNET, CELLPHONE, and FXBROADBAND variables are positive and statistically significant in all models while the coefficients of COMPUTER variable are positive and statistically significant in all models except Model 3, indicating that ICT penetration seems to increase tax revenue.

Table 4. Bivariate Model Estimation Results (INTERNET)

\begin{tabular}{|c|c|c|c|}
\hline & TAXREV (Model 1) & GOODTAX (Model 2) & VAT (Model 3) \\
\hline C & 1.4768 & 9.0168 & 3.0080 \\
\hline Standard Error & 0.2601 & 0.1892 & 0.1738 \\
\hline P-value & 0.0000 & 0.0000 & 0.0000 \\
\hline INTERNET & 0.0931 & 0.0487 & 0.0219 \\
\hline Standard Error & 0.0079 & 0.0053 & 0.0069 \\
\hline P-value & 0.0000 & 0.0000 & 0.0015 \\
\hline Number of Observations & 1894 & 1788 & 840 \\
\hline Number of Countries & 157 & 153 & 101 \\
\hline R-squared & 0.0824 & 0.0443 & 0.0859 \\
\hline Estimated Model & FEM & REM & FEM \\
\hline Hausman-statistics & 18.664 & 0.0652 & 30.7352 \\
\hline
\end{tabular}

Table 5. Bivariate Model Estimation Results (CELLPHONE)

\begin{tabular}{|c|c|c|c|}
\hline & TAXREV (Model 1) & GOODTAX (Model 2) & VAT(Model 3) \\
\hline C & 11.6336 & 6.3593 & 2.6689 \\
\hline Standard Error & 0.4090 & 0.3327 & 0.2090 \\
\hline P-value & 0.0000 & 0.0000 & 0.0000 \\
\hline CELLPHONE & 0.0816 & 0.0599 & 0.0164 \\
\hline Standard Error & 0.0053 & 0.0043 & 0.0028 \\
\hline P-value & 0.0000 & 0.0000 & 0.0000 \\
\hline Number of Observations & 1517 & 1422 & 779 \\
\hline Number of Countries & 152 & 145 & 97 \\
\hline R-squared & 0.1448 & 0.1298 & 0.0425 \\
\hline Estimated Model & FEM & FEM & REM \\
\hline Hausman-statistics & 51.304 & 30.033 & 2.976 \\
\hline
\end{tabular}


Table 6. Bivariate Model Estimation Results (COMPUTER)

\begin{tabular}{|c|c|c|c|}
\hline & TAXREV (Model 1) & GOODTAX (Model 2) & VAT (Model 3) \\
\hline C & 15.2827 & 9.2618 & 2.9497 \\
\hline Standard Error & 0.2830 & 0.2158 & 0.1952 \\
\hline P-value & 0.0000 & 0.0000 & 0.0000 \\
\hline COMPUTER & 0.1004 & 0.0380 & -0.0026 \\
\hline Standard Error & 0.0114 & 0.0095 & 0.0093 \\
\hline P-value & 0.0000 & 0.0001 & 0.7787 \\
\hline Number of Observations & 1092 & 1030 & 418 \\
\hline Number of Countries & 135 & 129 & 87 \\
\hline R-squared & 0.0659 & 0.0533 & 0.0880 \\
\hline Estimated Model & REM & FEM & FEM \\
\hline Hausman-statistics & 0.3261 & 10.579 & 9.437 \\
\hline
\end{tabular}

Table 7. Bivariate Model Estimation Results (FXBROADBAND)

\begin{tabular}{|c|c|c|c|}
\hline & TAXREV (Model 1) & GOODTAX (Model 2) & VAT (Model 3) \\
\hline C & 16.0710 & 10.1374 & 3.6493 \\
\hline Standard Error & 0.2879 & 0.2408 & 0.1781 \\
\hline P-value & 0.0000 & 0.0000 & 0.0000 \\
\hline FXBROADBAND & 0.1884 & 0.0900 & 0.0657 \\
\hline Standard Error & 0.0225 & 0.0183 & 0.0240 \\
\hline P-value & 0.0000 & 0.0000 & 0.0064 \\
\hline Number of Observations & 1240 & 1157 & 601 \\
\hline Number of Countries & 147 & 139 & 91 \\
\hline R-squared & 0.0663 & 0.0206 & 0.0499 \\
\hline Estimated Model & FEM & REM & FEM \\
\hline Hausman-statistics & 9.2753 & 0.0019 & 10.571 \\
\hline
\end{tabular}

As a part of robustness test, multivariate estimation results indicate the following;

1.) Estimation results using INTERNET as independent variable indicate that:

All coefficients of INTERNET variable are statistically significant and take the expected signs in all models, indicating that ICT penetration in the form of percentage of individuals using the internet seems to increase tax revenue.

In regard to other variables in the model, the estimated coefficient of GDP per capita growth variable takes the theoretically expected positive sign and is statistically significant in all models but Model 1 in line with other studies. Thus, the development of the economy seems to increase value added tax and taxes on goods and services. The coefficient of the OPENNESS variable is significantly positive in all models except Model 3. The results support the proposition that trade openness is positively correlated with tax revenue and taxes on goods and services. This is also indicated by study of Gupta (2007) who argued that trade-related taxes are easier to impose since the goods enter or leave the country at specified locations. The coefficient on FDI is significant and has expected positive sign in just Model 1. This result indicates that the flow of FDI increases tax revenue by boosting competitiveness and the formalization of the economy as argued by Gugler and Brunner (2007). 
Table 8. Multivariate Model Estimation Results (INTERNET)

\begin{tabular}{|c|c|c|c|}
\hline & TAXREV (Model 1) & GOODTAX (Model 2) & VAT (Model 3) \\
\hline C & 1.2853 & 8.0745 & 2.9190 \\
\hline Standard Error & 0.3819 & 0.2875 & 0.3430 \\
\hline P-value & 0.0000 & 0.0000 & 0.0000 \\
\hline INTERNET & 0.0769 & 0.0469 & 0.0256 \\
\hline Standard Error & 0.0080 & 0.0055 & 0.0071 \\
\hline P-value & 0.0000 & 0.0000 & 0.0004 \\
\hline GDPPCGRO & -0.0137 & 0.1385 & 0.0744 \\
\hline Standard Error & 0.0458 & 0.0336 & 0.0288 \\
\hline P-value & 0.7641 & 0.0000 & 0.0101 \\
\hline FDI & 0.0102 & 0.0043 & 0.0075 \\
\hline Standard Error & 0.0043 & 0.0039 & 0.0049 \\
\hline P-value & 0.0179 & 0.2721 & 0.1239 \\
\hline OPENNESS & 0.0231 & 0.0057 & -0.0035 \\
\hline Standard Error & 0.0035 & 0.0027 & 0.0034 \\
\hline P-value & 0.0000 & 0.0374 & 0.3019 \\
\hline Number of Observations & 1852 & 1760 & 817 \\
\hline Number of Countries & 155 & 152 & 101 \\
\hline R-squared & 0.1124 & 0.0588 & 0.0927 \\
\hline Estimated Model & FEM & REM & FEM \\
\hline Hausman-statistics & 31.171 & 3.8418 & 27.743 \\
\hline
\end{tabular}

2.) Estimation results using CELLPHONE as independent variable indicate that:

All coefficients of CELLPHONE variable are statistically significant at 1 percentage level and take the expected signs, indicating that ICT penetration in the form of mobile-cellular telephone subscriptions per 100 inhabitants seems to increase tax revenue.

The coefficients of GDPPCGR variable are positive and statistically significant in all models except Mo-

Table 9. Multivariate Model Estimation Results (CELLPHONE)

\begin{tabular}{|c|c|c|c|}
\hline & TAXREV (Model 1) & GOODTAX (Model 2) & VAT (Model 3) \\
\hline C & 11.0888 & 5.8518 & 2.6008 \\
\hline Standard Error & 0.4943 & 0.3926 & 0.3581 \\
\hline P-value & 0.0000 & 0.0000 & 0.0000 \\
\hline CELLPHONE & 0.0715 & 0.0605 & 0.0184 \\
\hline Standard Error & 0.0057 & 0.0046 & 0.0029 \\
\hline P-value & 0.0000 & 0.0000 & 0.0000 \\
\hline GDPPCGRO & -0.0570 & 0.1907 & 0.0765 \\
\hline Standard Error & 0.0510 & 0.0412 & 0.0272 \\
\hline P-value & 0.2641 & 0.0000 & 0.0051 \\
\hline FDI & 0.0110 & 0.0042 & 0.0056 \\
\hline Standard Error & 0.0043 & 0.0040 & 0.0050 \\
\hline P-value & 0.0123 & 0.2969 & 0.2644 \\
\hline OPENNESS & 0.0114 & -0.0017 & -0.0041 \\
\hline Standard Error & 0.0039 & 0.0032 & 0.0035 \\
\hline P-value & 0.0044 & 0.5756 & 0.2462 \\
\hline Number of Observations & 1473 & 1401 & 763 \\
\hline Number of Countries & 149 & 144 & 97 \\
\hline R-squared & 0.1506 & 0.1394 & 0.0586 \\
\hline Estimated Model & FEM & FEM & REM \\
\hline Hausman-statistics & 69.022 & 27.028 & 3.196 \\
\hline
\end{tabular}


del 1 while the coefficients of FDI and OPENNESS variables are positive and statistically significant in only Model 1.

3.) Estimation results using COMPUTER as independent variable indicate that:

All coefficients of COMPUTER variable are statistically significant at 1 percentage level and take the expected signs except Model 3, indicating that ICT penetration in the form of personal computers per 100 people seems to increase tax revenue.
The coefficients of GDPPCGR variable are positive and statistically significant in all models except Model 1. The coefficient of OPENNESS variable is positive and statistically significant in Model 1 while the coefficients of OPENNESS variable are negative and statistically significant in Model 2 and 3, indicating ambiguity of the sign of OPENNESS variable. The coefficients of FDI variable are positive and statistically significant in all models except Model 3.

Table 10. Multivariate Model Estimation Results (COMPUTER)

\begin{tabular}{|c|c|c|c|}
\hline & TAXREV (Model 1) & GOODTAX (Model 2) & VAT (Model 3) \\
\hline C & 14.1732 & 8.7969 & 3.1914 \\
\hline Standard Error & 0.4240 & 0.3222 & 0.4428 \\
\hline P-value & 0.0000 & 0.0000 & 0.0000 \\
\hline COMPUTER & 0.0787 & 0.0454 & 0.0005 \\
\hline Standard Error & 0.0119 & 0.0092 & 0.0094 \\
\hline P-value & 0.0000 & 0.0000 & 0.9528 \\
\hline GDPPCGRO & 0.0100 & 0.1681 & 0.1038 \\
\hline Standard Error & 0.0577 & 0.0440 & 0.0398 \\
\hline P-value & 0.8624 & 0.0001 & 0.0095 \\
\hline FDI & 0.0306 & 0.0188 & 0.0121 \\
\hline Standard Error & 0.0098 & 0.0074 & 0.0079 \\
\hline P-value & 0.0018 & 0.0112 & 0.1240 \\
\hline OPENNESS & 0.0096 & -0.0059 & -0.0092 \\
\hline Standard Error & 0.0045 & 0.0033 & 0.0045 \\
\hline P-value & 0.0318 & 0.0773 & 0.0408 \\
\hline Number of Observations & 1064 & 1009 & 405 \\
\hline Number of Countries & 132 & 127 & 86 \\
\hline R-squared & 0.0870 & 0.0463 & 0.1042 \\
\hline Estimated Model & REM & REM & FEM \\
\hline Hausman-statistics & 2.0383 & 7.4317 & 14.1679 \\
\hline
\end{tabular}

4.) Estimation results using FXBROADBAND as independent variable indicate that:

All coefficients of FXBROADBAND variable are statistically significant at 1 percentage level and take the expected signs, indicating that ICT penetration in the form of fixed broadband subscriptions per 100 people seems to increase tax revenue.
The coefficients of GDPPCGR variable are positive and statistically significant in all models except Model 1 while the coefficients of FDI and OPENNESS variables are positive and statistically significant in only Model 1. 
Table 11. Multivariate Model Estimation Results (FXBROADBAND)

\begin{tabular}{|c|c|c|c|}
\hline & TAXREV (Model 1) & GOODTAX (Model 2) & VAT (Model 3) \\
\hline C & 14.9917 & 8.8905 & 3.0879 \\
\hline Standard Error & 0.4621 & 0.3842 & 0.4320 \\
\hline P-value & 0.0000 & 0.0000 & 0.0000 \\
\hline FXBROADBAND & 0.1795 & 0.1012 & 0.0651 \\
\hline Standard Error & 0.0240 & 0.0192 & 0.0249 \\
\hline P-value & 0.0000 & 0.0000 & 0.0092 \\
\hline GDPPCGRO & -0.0711 & 0.1795 & 0.0727 \\
\hline Standard Error & 0.0604 & 0.0465 & 0.0353 \\
\hline P-value & 0.2390 & 0.0001 & 0.0400 \\
\hline FDI & 0.0096 & 0.0027 & 0.0087 \\
\hline Standard Error & 0.0045 & 0.0045 & 0.0063 \\
\hline P-value & 0.0353 & 0.5357 & 0.1701 \\
\hline OPENNESS & 0.0113 & 0.0057 & 0.0016 \\
\hline Standard Error & 0.0040 & 0.0034 & 0.0043 \\
\hline P-value & 0.0054 & 0.1021 & 0.7011 \\
\hline Number of Observations & 1203 & 1144 & 588 \\
\hline Number of Countries & 145 & 139 & 91 \\
\hline R-squared & 0.0894 & 0.0401 & 0.0623 \\
\hline Estimated Model & FEM & REM & FEM \\
\hline Hausman-statistics & 21.463 & 3.0450 & 11.506 \\
\hline
\end{tabular}

Among the four ICT indicators, FXBROADBAND is the most contributing one to tax revenues in terms of total, tax on goods and services, and value-added tax. Overall, our results indicate that ICT penetration contributes to increase in tax revenue in the period 1990 to 2013.

\section{Conclusion}

In addition to other determinants of tax revenue, this study examines the explanatory power of ICT penetration on tax revenue. By using four ICT penetration indicators and three tax revenue indicators, we test the hypothesis that ICT penetration contributes to increase in tax revenue over the period 1990 to 2013. The sample includes 157 economies. We identified a positive correlation between ICT penetration and tax revenue. This finding is statistically significant and valid for four ICT penetration indicators and three tax revenue indicators. Thus, the results suggest that ICT penetration increases tax revenue, controlling for other factors that may contribute to increase in tax revenue. Moreover, among the four ICT indicators, FXBROADBAND is the most contributing to each of three distinct tax revenues.

\section{References}

Bahl, R., Wallace, S. (2005). Public Financing in Developing and Transition Countries. Public Budgeting \& Finance, 25(4), 83-98.

Bird, R.M., Martinez-Vazquez, J., Torgler, B. (2004). Societal Institutions and Tax Effort in Developing Countries. International Studies Program Working Paper 04-06, Atlanta: Georgia State University.

Bird, R.M., Martinez-Vazquez, J., Torgler, B. (2008). Tax Effort in Developing Countries and High Income Countries: The impact of Corruption Voice and Accountability. Economic Analysis and Policy 38 (1), 55-71.

Cassou, S.P. (1997). The Link Between Tax Rates and Foreign Direct Investment. Applied Economics 29 (10), 1295-1301.

Castro, G.A., Camarillo, D.B.R. (2014). Determinants of Tax Revenue in OECD Countries over the period 2001-2011. Contaduria y Administracion, 59 (3), 35-59. 
Chelliah, R.J., Baas, H.J., Kelly, M.R. (1975). Tax Ratios and Tax Effort in Developing Countries, 1969-71. IMF Staff Papers, 22, 187-205.

Ghura, D. (1998). Tax Revenue in Sub Saharan Africa: Effects of Economic Policies and Corruption. IMF Working Paper 98/135, Washington D.C.: International Monetary Fund.

Gugler, P., Brunner, S. (2007). FDI Effect on National Competitiveness: A Cluster Approach. International Advances in Economic Research, 13 (3), 268284.

Gupta, A. S. (2007). Determinants of Tax Revenue Efforts in Developing Countries. IMF Working Paper 07/184, Washington D.C.: International Monetary Fund.

HM Revenue and Customs (2015). Making Tax Easier: The End of Tax Return. HM Revenue and Customs Corporate Communications, UK.

Vu, K.M. (2011). ICT as a Source of Economic Growth in the Information Age: Empirical Evidence from the 1996-2005 Period. Telecommunications Policy, $35,357-372$.

Leuthold, J.H. (1991) Tax Shares in Developing Countries: A Panel Study. Journal of Development Economics, 35, 173-185.

Pessino, C., Fenochietto, R. (2010). Determining Countries' Tax Effort. Revista de Economía Pública 195 (4), 65-87.
Piancastelli, M. (2001). Measuring Tax Effort of Developed and Developing Countries: Cross Country Panel Data Analysis 1985-1995. Working Paper 818, Institute of Applied Economic Research, Rio de Janeiro: Brazil.

Pradhan, P.P, Arvin, M.B., Norman, N.R., Bele, S.K. (2014). Economic Growth and the Development of Telecommunications Infrastructure in the G-20 Countries: A Panel-VAR Approach. Telecommunications Policy, 38, 634-649.

Stotsky, J.G., WoldeMariam, A. (1997). Tax Effort in Sub Saharan Africa. IMF Working Paper 97/107, Washington D.C.: International Monetary Fund.

Tait, A.A., Eichengreen, B.J., Grätz, W.L.M. (1979). International Comparisons of Taxation for Selected Developing Countries, 1972-76. IMF Staff Papers, $26,123-156$.

Tanzi, V. (1988). The Impact of Macroeconomic Policies on the Level of Taxation (and on the Fiscal Balance) in Developing Countries. IMF Working Paper 88/95, Washington D.C.: International Monetary Fund.

Tanzi, V. (1992). Structural Factors and Tax Revenue in Developing Countries: A Decade of Evidence. Ian Goldin and L. Alan Winters (Ed.), in Open Economies: Structural Adjustment and Agriculture, (pp. 267-281). Cambridge: Cambridge University Press.

Teera, J.M., Hudson, J. (2004). Tax Performance: A Comparative Study. Journal of International Development, 16 (6), 785-802. 